\title{
Kadro Hareketi ve Bir Kadro Kitabı Olarak Ankara
}

\author{
MURAT DEVRIM DIRLIKYAPAN*
}

\begin{abstract}
ÖZ
Ocak 1932 - Aralık 1934 arasında üç yıl gibi kısa bir süre yayımlanan Kadro dergisi, ancak "iktidara sözcü olma" görevini yerine getirebilmiş, bu görevin aksayıp iktidarın gücünü zedelemeye dönüşebileceği yerde ise işlevi sorgulanmaya başlanmış ve bir anlamda "öncü bir kadro” olmasına izin verilmemiş bir dergidir. Dolayısıyla Kadro'nun hem sosyalizm ve kapitalizm arasında bir "üçüncü yol" arayışı, hem de öncü olma "hevesi”, bir ütopya olarak kalmıştır. Kadro'nun önemli isimlerinden Yakup Kadri Karaosmanoğlu'nun Ankara adlı romanı, büyük bir “inkılâp heyecanı"yla yayınına başlanan, ardından sessizce kapanan ve bir ütopyaya dönüşen Kadrónun kurmaca bir ifadesi olarak okunabilir. Bu yazıda Kadro hareketinin iktidar ile ilişkisine değinilecek, ideolojik eğilimi tartışlacak ve hareketin öncü isimlerinden Yakup Kadri'nin Ankara romanında yer alan bazı fikir ve tartışmalar, bu hareket ekseninde okunacaktır.
\end{abstract}

Anahtar sözcükler: Cumhuriyet, iktidar, Kadro, Yakup Kadri Karaosmanoğlu, Ankara

Kadro, Şevket Süreyya Aydemir, Burhan Asaf Belge, Yakup Kadri Karaosmanoğlu, İsmail Hüsrev Tökin, Vedat Nedim Tör ve Mehmet Şevki Yazman'dan oluşan altı kişilik bir grubun üç yıl gibi kısa bir süre yayımladıkları bir derginin adı olmasının yanında, üzerinde çok tartışılmış bir hareketin de adıdır. "İnkılâba öncü bir kadro gerektiğì" düşüncesinden hareket ederek yayınına başlayan dergi, bir yandan iktidarı etkileyebilmek için onun sözcüsü olmak durumunda kalmış, öte yandan inkılâbın bittiğini düşünerek karamsar bir havaya bürünen iktidar sahiplerinin ve yanlış yöne giden Cumhuriyet'in bir eleştirisi olmuştur. Yakup Kadri'nin Ankara adlı romanı ise, Kadro'nun bu gibi düşüncelerinin roman biçimindeki bir ifadesi olarak değerlendirilebilir.

\footnotetext{
"Yrd. Doç. Dr., Çağ Üniversitesi, Türk Dili ve Edebiyatı Bölümü / MERSİN e-posta:dirlikyapan@cag.edu.tr
} 
Bu çalışmada Kadro hareketinin ideolojik eğilimi ve iktidar ile olan ilişkisi ele alınacak, Kadro dergisinin öne çıkan görüşlerinin Yakup Kadri'nin Ankara adlı romanındaki etkisi üzerinde durulacaktır.

\section{Kadro ve İktidar}

"Kadro" düşüncesinin, hareketin ideolojik önderi olarak kabul edilen Şevket Süreyya Aydemir'in, 15 Ocak 1931'de "İnkılâp ve Kadro" başlıklı konferansı ile başladığı söylenebilir." Bu konferansta Şevket Süreyya, Ankara'daki karamsar havaya kapılmamak gerektiğini, inkılâbın bitmediğini ve bütün amelî ve fikrî unsurlarının tam olduğunu, bunun derinleşip halkın şuurunda yerleşebilmesi için bir fikir sistemi içinde derlenmesi gerektiğini ifade eder. Şevket Süreyya'ya göre inkılâp köye girmeliydi ve genel buhran karşısında "strüktürel" çıkış yolları aranmalıydı. "Bunalım içinde bu ruh düşkünlüğünden kurtulmanın yolu, her şeye rağmen inkılaba sarılmak ve onu derinleştirmekti. Yaşanan bu sorunların nedeni inkılâbın dinamik prensiplerinin yeterince işlenememiş olmasıydı. Bu açıklamayı ve işlemeyi yapacak olan da 'öncü bir kadroydu"' (Tekeli, İlkin 2003: 129).

Kadro dergisinin Ocak 1932'de çıkan ilk sayısındaki düşünceler, Şevket Süreyya'nın bu konferansta dile getirdiği görüşlerin daha geniş bir şekli gibidir. Nitekim Kadro'nun ilk başyazısında temel olarak şu düşünceler öne çıkmaktadır:

Türkiye bir inkılâp içindedir. Bu inkılâp kendine prensip ve onu yaşatacaklara şuur olabilecek bütün nazarî ve fikrî unsurlara maliktir. Ancak bu nazarî ve fikrî unsurlar inkılâba "ideoloji" olabilecek bir fikriyat sistemi içinde terkip ve tedvin edilmiş değildir. [...] İnkılâbımızın, her biri ayrı ayr kıymettar ve orijinal olan bu fikir ve nazariye unsurları birer birer izah edildikçe, bu esaslar inkılâp nesli için kriteryumlar olacak, yeni ve standartlaşmı̧̧ inkılâp̧̧ı tip böyle doğacak [....] İnkılâbın kendisine has "cihanı telâkkî tarzı" böyle vücut bulacaktır ("Kadro [1]"1932: 3).

Başyazı, inkılâp neslinin muhtaç olduğu inkılâp şevkini uyanık tutmak için onun prensiplerini "bilmeye, benimsemeye ve benimsetmeye mecburuz" sözleriyle devam etmekte, derginin çıkış nedeni de buna bağlanmaktadır. Burada dikkati çeken önemli bir nokta, Kadro'nun iktidarın bir yayın organıymıs gibi konuşmasıdır. Oysa inkılâbı gerçekleştirenler Kadrocular olmadığı gibi, Kadro da iktidarın siyasî bir yayın organı, örneğin Cumhuriyet Halk Fırkası'nın

\footnotetext{
"Bu konferansın metni, daha sonra bir broşür olarak basılmış, buradan alınan bazı bölümler ise, Kadro'nun 7. sayısında "Millî Kurtuluş Hareketlerinin Ana Prensipleri” başlı̆̆ıyla yayımlanmıştır. Kitap olarak da basılan İnkılâp ve Kadro, en kapsamlı halini 1968 yılında Bilgi Yayınevi'nce yapılan ikinci baskısıla almıştır.
} 
bir yayını değildir. Yayın kurulunu oluşturan kişilerin çoğu "komünist" olan ve her biri birkaç yıl önce bu nedenle yargılanmış ve çeşitli cezalar almış, daha sonra da devlet tarafindan affedilmiş bir grubun dergisidir. Buna rağmen iktidara özgü bir "yukarıdan” söylemle, inkılâbın devam ettiği, inkılâba bir ideoloji gerektiği, bunu da öncü bir "kadro"nun yapabileceği gibi düşünceler üretmektedirler. İktidara "kadro" olarak önerdikleri de, elbette kendileridir.

Ancak, kadro olarak kendilerini önermeleri, kendi çıkarlarını düşündükleri için değildir. Aksine, inkılâbın kişisel çıkarlar nedeniyle yolundan saptığı görüşündedirler. Şevket Süreyya'nın İnkılâp ve Kadro'da belirttiği gibi "Kadro, milletin bütününü bağlayan bir milli kurtuluş hareketinde, millet içinde bir menfaat kavgasını temsil eden dar bir menfaat zümresinin mücadele organı değildir. Bu hareketi duyan, koruyan ve yaşatan ileri unsurların, öncü teşkilatıdır" (1968: 258). İnkılâbın küçük hesaplar, çıkarlar, entrikalar ve bürokrasi yüzünden devam edemediğini, başka bir deyişle "büyük inkılâp"ın "küçük politika”lar yüzünden nasıl "kementlendiğini” anlamak için Yakup Kadri’nin "Büyük İnkılâp ve Küçük Politika" başlığını taşıyan yazı dizisine bakmak gerekir. Cumhuriyet'in onuncu yılı için yazılmış ama Kadro dergisi kapandığ için yayımlanamayan bu yazı dizisi, Yakup Kadri'nin ölümünden sonra eşi Leman Hanım tarafindan bulunmuş ve 13-22 Aralık 1976 tarihlerinde Milliyet gazetesinde tefrika edilmiştir. Daha sonra yazarın Atatürk adlı kitabına alınan bu yazılarda Yakup Kadri, inkılâp hamlesine iki türlü irticanın kement vurduğunu ifade eder (2000: 157). Mektepli ve medreseli olmak üzere birbirine zıt görünen bu iki softa tipi, Tanzimat'tan beri varlığını korumakta ve inkılâp karşısında el ele yürümektedir. Yakup Kadri'ye göre Türk ink1lâp tarihi, "mektepli softa" çelişkisinde olduğu gibi "binlerce tezatlar ve birbirini tutmaz hareketlerle doludur". Bunun en belirgin nedenlerinden biri, inkılâbın "bir inkılâpçı kadrosundan ve bir hareket ve taktik planından mahrumiyetidir". Yazar, inkılâp tarihi "bir tek kahramanın ulvî ve hazin sergüzeştinden ibarettir" diyerek Mustafa Kemal'i yüceltir. Çünkü "nereden gelip nereye gittiğini ve ne yapıp ne yapmayacağını bilen” yalnızca odur (2000: 173).

Kadro'nun ilk sayılarında ele aldığ konulara genel olarak bakıldığında inkılâba sahip çıktıkları ve bunu devam ettirmek istedikleri, tek iktidar durumunda olan CHF'nin programını da destekledikleri görülmektedir. Örneğin, sonradan "Cumhuriyet' in ilkeleri” adını alacak olan ve CHF'nin "Altı ok"unu belirleyen ilkelerden sonuncusu olan "devletçilik" ilkesi, "laiklik" ve “devrimcilik" ilkeleriyle birlikte, 1931'de kabul edilmiş ve partinin tüzüğüne girmiş̧ir. Kadro dergisi de çoğunlukla bu ilke etrafında ya da bu ilkeye uygun politikalar üretmeye çalışmıştır. Kadro'nun her sayısında bir "devlet" vurgusu dikkati çekmektedir. İktisatta planlamacı ve müdahaleci görüşü savunmaları da bu noktada onların iktidar gibi ya da iktidarın sözcüsü gibi davrandık- 
larını ortaya koymaktadır. Örneğin, Kadro'nun ikinci sayısında Vedat Nedim, Türkiye'nin bir "iktisat devleti” olması gerektiği düşüncesini, bir "tabî̂ tekâmül” eleştirisi üzerine kurmuştur:

İktisadiyatımızın talihini 'tabiî tekâmül'ün cilvelerine terk edemeyiz. İnkılâp, inkılâpçı hamlelerle tekâmül eder. Her vatandaş, şapkanın lüzûmuna kani olsun diye beklemedik! Her vatandaş, yeni harflerimizin zaruretine inansın diye beklemedik! Her vatandaş, mecellenin köhneliğine isyan etsin diye beklemedik! İktisat sahasında da "aynı" ölçünün hâkim olmasını istemek hakkımızdır. ("Müstemleke İktisadiyatından...”1932: 9)

Başka bir örnek olarak da "Millî İktisat ve Tasarruf Cemiyeti"nin ülkenin her yerinde düzenlemeye başladığı "tasarruf ve yerli malı haftası" verilebilir. İlk sayıda bu uygulamanın önemine vurgu yapan Kadro dergisi, tasarruf etmenin ve yerli malı kullanmanın "halk destanları" ile ilgisini kurmakta ve daha sonraki sayılarında Yakup Kadri'nin "yerli malı" ile ilgili halk destanları hakkındaki yazılarını yayımlamaktadır. İktidarın bu gibi uygulamalarını destekleyen Kadro'nun, inkılâbı onlar yapmış gibi bir tutum içinde, başka bir deyişle iktidarın sözcüsü durumunda olmaları, "inkılâp öncü bir azınlığa değil, halka aittir" düşüncesinden hareket etsek bile, "yukarıdan” bir söyleme sahip olduğu için yadırgatıcıdır. Nitekim inkılâbın asıl sahipleri, daha doğru bir deyişle iktidarın bizzat kendisi olan CHP'nin içinde yer alan bazı gruplar da tepki göstermekte gecikmemişlerdir. Kadro'nun daha ikinci sayısında yer alan “yüzük hikâyesi” bile yoğun tepkilere neden olmuştur. Bu hikâyeden hareketle Kadro, "Türkiye'de herkes, 'milliyetçilik' yüzüğünün yalnız kendinde olduğu iddiasındadır" ("Kadro [2]” 1932: 3) diyerek yüzüğün asıl sahibinin kim olduğunu "Türk münevverliğine ve Türk tarihine" bıraksa da, asıl sahibin kendileri olduğunu ima etmekten de geri durmamıştır: "Hakiykî yüzük kimdedir? 'Kadro' bu suale, millet davasına bağlı olmasındaki ileri şuur ve ileri iymanla cevap vermeği daima tercih edecek[tir]"(1932: 4).

Burada Kadro'nun “iktidar sözcüsü” söyleminin "iktidarı etkileme” niyetini barındırdığı da açıktır. İlhan Tekeli ve Selim İlkin' in Kadrocuları ve Kadro'yu Anlamak adlı kitabında söz ettiği gibi, bir ülkenin sorunlarına çözüm önerileri geliştirmek ve var olan iktidarı da bu çözümlerin doğruluğuna inandırmak, iktidarı bu yönde etkilemeye çalışmak, Türkiye gibi ülkelerin aydınlarının "hemen hepsinin gönlünde yatan bir durumdur" (2003: 10). Kadro, inkılâb1 benimsemiş ve bunu iktidarı etkilemek suretiyle daha ileriye götürmek istemiş, ancak bunda başarılı olamamıştır. Çünkü yukarıda da ifade edildiği gibi, "yukarıdan" bir söylemle "kadro" olarak kendilerini görmeleri, CHP içinde birçok tepkiye neden olmuştur. Örneğin CHP umum kâtibi Recep Peker, Kadro'ya karşı açıkça cephe almış ve “eğer gerekiyorsa CHP'ye ideolojiyi biz 
üretiriz” demiştir (aktaran Türkeş 2002: 476). Giderek CHP ile arasını açan ve parti programıla da çelişkiye düşen Kadro'nun son sayılarında, özellikle "toprak reformu” ve "sanayileşmenin devlet eliyle kontrolü" gibi konular, Mustafa Kemal'in sofrasına kadar bir şikâyet olarak taşınmaya başlamıştır. Örneğin, toprak reformu konusunda Kadro'nun son derece 1srarlı olmasına rağmen, CHP, bunu öncelikli bir konu olarak görmemektedir. Benzer şekilde, sanayileşme konusunda da çelişkiye düşülmüştür. Kadro, 1933’teki sanayi planını eksik bulmuş ve CHP'nin daha radikal kararlar almasını istemiştir. Özel sektörün siyasî olarak güçlenmesine karşı oldukları için, bu sektörün ekonomik olarak da devlet tarafından kontrol edilmesi gerektiğini savunmuşlardır. Bu gibi düşünceler, CHP tarafından "komintern propagandası yapmak" şeklinde kavranmıştır (2002: 475). Dolayısıyla ilk sayılarında "iktidar sözcüsü" gibi görünen Kadro'nun, giderek iktidar için ancak bir şikâyet konusu olabildiği söylenebilir. Yakup Kadri’nin, derginin kapanış öyküsünü de anlattı̆̆g Zoraki Diplomat'ta belirttiği gibi, "Kadro küçük bir dergiydi ama, iddiası büyüktü. İşbaşında bulunan 'resmî' şahsiyetleri de, sanırım, en çok bu hali, bu 'haddini bilmemezliği' sinirlendiriyordu” (2006: 36).

Mustafa Türkeş, “[i]ktidarın uyguladığı iktisat politikalarının bir kısmını desteklemek Kadro'nun iktidar ile aynı şeyleri savunduğunu elbette göstermez. Kadro, CHP'nin her iki kanadından (İnönü ve Bayar) da ideoloji ve gelişme stratejisi önerileriyle ayrılmaktadır” demektedir (2002: 467). Doğrudur, ancak bu da, Kadro'nun iktidarın sözcüsü olmak durumunda kaldığ1 gerçeğini değiştirmez. Yine Türkeş’in belirttiği gibi Kadro, kendisini salt rejimi destekleyen bir aydın grubu olarak görmemiş, iktidar ile kendisi arasındaki farklı yaklaşımları vurgulamaktan da geri durmamıştır. Bu noktada Kadro'yu "salt rejimin kullandığı bir araç olarak değerlendirmek yanlış” olacaktır. Kadro, iktidar için olsa olsa başarısız bir "deneme"dir.

Üç yıl gibi son derece kısa bir süre yayımlanan Kadro, ancak “sözcülük” görevini yerine getirebilmiş, bu görevin aksayıp iktidarı etkilemeye dönüşebileceği yerde ise engellenmiş, bir anlamda "öncü bir kadro" olmasına izin verilmemiştir. İmtiyaz sahipliğini Mustafa Kemal'in "sofra arkadaşlarından biri” olan Yakup Kadri’nin yaptığ 1 derginin, yayımlanmaya Gazi'den aldığı destekle başladığ ve yine ondan aldığg yardımlarla yayınını sürdürdüğü bilinmektedir. Derginin kapanışı ise, Yakup Kadri'nin Atatürk tarafından Tiran'a elçi tayin edilmesiyle olmuştur. Atatürk, Yakup Kadri’nin ifadesiyle hem bazı "resmî şahsiyetleri” teskin etmek hem de Yakup Kadri'nin haysiyetini kırmamak için doğrudan dergiyi kapattırmamış, yazarı ortamdan uzaklaştırma yoluna gitmiştir (2006: 28). Yakup Kadri bu durumu Zoraki Diplomat'ta bir satranç metaforuyla anlatır: "Lâkin, ben politikanın satranç tahtası üstünde sadece bir 'piyade' idim. Ne mat edilmeğe değerdim, ne de başlıca bir rolüm olabilirdi. Onun içindir ki, 
hünerli satranç ustası beni bir ileri sürdü, bir geri çekti ve sonunda karşımdaki fil'e esir vermekte hiçbir zarar görmedi” (2006: 38).

Yakup Kadri'nin Tiran'a gönderilmesi, düşüncelerinde bir hayli kararlı ve mücadeleci görünen diğer Kadro yazarlarının da bu kararlılık ve heyecanlarından oldukça çabuk bir şekilde vazgeçmelerine, susmalarına yetmiştir. Sonuçta, "solun kalkınmacı söylemleriyle ulusçuluğu birleştirmeye çalışan $\mathrm{Kad}$ ro, gelişme stratejisi önerisiyle kapitalizme ve sosyalizme alternatif üçüncü bir yol üretememiş, kapitalizm içinde değerlendirilebilecek bir seçenek" olarak kalmıştır (Türkeş 2002: 476). Büyük bir “inkılâp heyecanı”yla yayın hayatına başlayan Kadro, sessizce kapanıvermiştir.

\section{Kadro'nun İdeolojik Eğilimi}

Kadro'da yayımlanan yazılara genel olarak bakıldığında iktisadi konuların daha ağırlıkta olduğu görülür. Vedat Nedim, "Millet İktisadiyatı” köşesinde, İsmail Hüsrev ise, “Cihan İktisadiyatı”, “İktisadî Kronik” ve "Millî İktisat Tetkikleri” başlıklı köşelerde iktisat konularında öncülüğü üstlenmişlerdir. Derginin ideolojik konumunu belirleyen yazılar, çoğunlukla Şevket Süreyya tarafından "İnkılâbın Psikolojisi", "İnkılâbın İdeolojisi” ve "Polemik" başlığını taşıyan köşelerde dile getirilir. "Cihan İçinde Türkiye” başlıklı köşede ise Burhan Asaf, dış siyaset konularına eğilir. Yakup Kadri edebiyat konularına yoğunlaşırken, Kadro'ya 13. sayıdan itibaren katılan Mehmet Şevki ise, daha çok "teknolojik gelişme" konularını ele alır.

Kadro'nun çıktığı yıllarda hükümetin uygulamaya çalıştığ1 planlı devletçiliğe karşı, Türkiye İktisat Kongresi'nde olduğu gibi, epeyce yaygın bir liberalist eleştiri bulunmaktadır. Kadro bu liberal kesime karşı mücadeleye girişerek işe başlamıştır. Derginin neredeyse her sayısında bir "liberalizm” eleştirisi ve "devletçilik" savunusu dikkati çeker. Örneğin, ilk sayıda Vedat Nedim, "Müstemleke İktisadiyatından Millet İktisadiyatına" başlığını taşıyan yazısında "İnkılâbın heyecanını ve mihverini artık iktisadî sahaya nakletmek zamanı geldi” (1932: 9) diyerek "plânlı iktisat" ın gerekliliğini vurgular: "Bütün dünya anarşik iktisattan plânlı iktisada doğru yürüyor. [....] Biz, böyle bir plânlı faaliyete her milletten daha ziyade muhtacız. Çünkü iktisadî bünyemizi değiştiriyoruz. Şuursuz iktisat siyasetinden, şuurlu iktisat siyasetine geçiyoruz" (1932: 11). Vedat Nedim, "emperyalizmin kucağına düşmemek" ve "diğer milletlere örnek olmak" gibi, iki önemli amacın altını çizerek, önlerinde taklit edebilecekleri hiçbir örneğin bulunmadığını, inkılâbın diğer unsurları gibi iktisadî inkılâbın da "orijinal bir eser" olacağını ifade eder (1932: 10). Bununla, sosyalizm ve kapitalizm arasında bir "üçüncü yol" arayışı içinde olduklarını da duyurmuş olur. Vedat Nedim, ikinci sayıda da bu konuya devam eder ve "yeni yolu açacak 
bir tek kuvvet tanyyoruz: 'Devlet'” der (1932: 9). Yine planlı iktisadı, iktisadın "ferd" in eline bırakılamayacağını savunur ve liberalizmi eleştirir:

Avrupa sanayi emteasının memleketimize serbestçe girebilmesi için 'Bırakın yapsın! Bırakın geçsin!' prensibinin de beraber girmesi şarttı. Fakat şimdi gümrük kapılarımız kontrolümüz altındadır. Kafalarımızın da gümrük kapılarını yabancı, çürük ve zararlı fikir emtaasına karşı kapatalım. İktisat siyasetimiz, 'yerli' prensipler istiyor! (1932: 11)

Burhan Asaf ise, "İnkılâbımız ve Hilâfet” başlıklı yazısında Türkiye'nin "ferdiyetçi iktisat nizamı"ndan "devletçi iktisat nizamı"na gittiğini övünçle karşılar ve Türk inkılâbının bir Tanzimat, yani körü körüne ve emperyalizme pazar vazifesi görebilmek için yapılmış bir hareket değil, a'dan z'ye milletin kurtarılması hareketi olduğunu belirtir (1932: 39).

Kadro dergisinde liberalizm karşıtlı̆̆ından sonra en çok dikkati çeken noktalardan biri de "Anti-Avrupamerkezcilik"tir. Örneğin, Şevket Süreyya, "İnkılap Bitti mi?" başlıklı yazısında bir "cihanı telâkki tarzı" olarak iki kutuptan söz eder. Bir tarafta "bir buçuk milyar müstemleke halk" ın yarattığı fazla kıymetlerle yaşayan, "bütün teknik vasıtaları kendi emrinde tutan ve cihanı kendi fikir ve iktisat diktatörlüğ̈̈ altında” yöneten sanayi Avrupa’sı vardır. Diğger yanda ise, "sınıflar kavgası” ve Avrupa'ya karşı "millî kurtuluş mücadeleleri” bulunur. Şevket Süreyya, bunlar arasında Türkiye'nin yerinin "millî kurtuluş hareketleri cephesinde” olduğunu ifade eder (1932: 7). “Europacentrisme'in Tasfiyesi” başlığını taşıyan başka bir yazısında ise, "Europacentrisme" ile "Geocentrisme"i karşılaştırarak her ikisini de bir "telâkki hatası" olarak niteler. Şevket Süreyyaya göre "Geocentrisme”, Copernic'e kadar büyük bir yanlış olarak insanlığa hükmetmiştir. Bu yanlışı bir "ilim” hâline getiren Batlamyos, dünyayı güneş sisteminin merkezi saymış ve bütün gerçekliği buradan açıklamaya çalışmıştır. "Batlamyos arzın haricindekini, arza tâbiy saymakla, beşer idrakini bir uzun devir için nasıl darlığa ve yanlışlığa mahkûm kılmışsa, Europacentrisme de Avrupa haricindekini Avrupa'ya tâbi saymakla beşerin tefekkür tarihinde o kadar geri ve o kadar menfî bir rol oynamıştı[r]" (1932: 5). Yazara göre Copernic, "Geocentrisme” yanlışına nasıl son vermişse, millî kurtuluş mücadeleleri de "Europacentrisme"e son vermiştir.

Kadro, liberalizme karşı çıktığı kadar, sosyalizme karşı değildir. Derginin 6. sayısındaki başyazıda ve Yakup Kadri'nin 7. sayıdaki "Ankara - Moskova - Roma” başliklı yazısında SSCB ve İtalya, "kafaca ve ruhça çökmüş olan garp cemiyetleri”nin karşısında konumlandırılır ve örnek alınması gereken devletler olarak savunulur. Başyazıda "iki büyük cemiyet hareketini temsil eden iki komşu memleketteki tetkik teşebbüslerini, hem doğru, hem cesaretli bir hareket olarak alıyor ve takdir ediyoruz" sözleri yer alır (1932: 4). Yakup Kadri ise, Sovyet devrimi ile İstiklâl harbi ve Rus Çarlığı ile Osmanlı İmpa- 
ratorluğu arasında bir karşılaştırma yapar ve çeşitli benzerlikler bulur. Türkiye Cumhuriyeti'ni, Birsen Talay'ın da ifade ettiği gibi, korunması gereken ink1lâplardan dolayı "güdümlü devlet sistemi" olarak adlandırır. Kadro'nun görevini de, gerçekleşen siyasî inkılâb1, "harsî, iktisadî ve idarî inkılâplarla tamamlamak" olarak ifade eder (2002: 439). Kadrocular sosyalizme karşımış gibi görünmezler, ancak onlara göre sosyalizmin Türkiye’de uygulanması, "uygun bir zemin" olmadığı için imkânsızdır. Buna karşın "plânlı iktisat"tan taviz verilmeden, Türkiye’ye has bir "üçüncü yol” bulunmalıdır.

Kadro'da Türkiye'nin bir "ziraat memleketi” olmasına karşı çıkıldığı ve sık sık sanayileşmeye vurgu yapıldığı görülür. Örneğin, Vedat Nedim, "Niçin ve Nasıl Sanayileşmemiz Lâzım?" başlğıını taşıyan yazısında dünyayı "sanayi memleketleri” ve "ziraat memleketleri” şeklinde bölmenin "müstemlekeci siyasetin doğurduğu bir tasnif şekli” olduğunu belirtir ve bu tasnifin sömürgeliği doğrudan kabul etmeye dayandığını ifade ederek, bu ayrıma şu şekilde karşı çıkar:

Türkiye'nin sadece bir sanayi memleketi olmasinı istemek kuru bir fantezidir. Fakat Türkiye'nin sadece bir ziraat memleketi kalmasını istemek de onun müstemlekeliğe rucuunu özlemekle birdir. Çünkü; ziraat memleketleri ile sanayi memleketleri arasındaki mübadele münasebetlerinde, birinciler aleyhine bir kıymet farkı vardır. İste müstemlekelerin istismar mekanizmasını işleten motor budur. Müstemlekelerde bir millî sermayenin teraküm edememesi, bundan ileri gelir. (1932: 14)

Vedat Nedim'e göre Türkiye'nin hem sanayi hem de ziraat alanında planlı bir kalkınmaya ihtiyacı vardır: "Ziraati sanayie, sanayii ziraate pazar yapacak ve ziraatle sanayiin birbiri için ahenkli inkişafını evvelden tespit edilmiş bir plana göre tanzim edecek bir millî iktisat siyaseti... Davamız budur” (1932: 15).

Mustafa Türkeş, Kadrocuların, oldukça karmaşık görünse de son analizde ideolojik eğilimlerinin net olduğunu söyler. Yazara göre Kadro, "[u]lusçuluğu tarihi materyalizmin içine yerleştirmeye çalışan, emperyalizm analizinde Lenin'den doğrudan etkilenen, pozitivist-modernizmi savunan, gelir ve kaynak dağılımı konularının burjuvazinin hegemonyasına bırakılmaması gerektiğini”, tam tersi, burjuvazinin devlet tarafindan kontrol altına alınmasını ssrarla dile getiren "radikal ulusçu sol bir yaklaşımın ifadesi”dir. Türkeş'e göre Kadro, "[u] lusçu solun Türkiye'deki ilk köklü ve sistematik savunucusudur” (2002: 470).

Kadro'nun imtiyaz sahibi Yakup Kadri ise, yukarıda da ifade edildiği gibi, dergide çoğunlukla edebiyat konularına yoğunlaşmış, ancak başka konularda da yazmıştır. Örneğin, Kadrónun 2. sayısındaki "Millî Tasarruf ve Halk Edebiyatı" adlı yazısında bütün halkın yerli malı kullanması gerektiğine dikkati çeker ve aydınlar ile halk arasındaki kopukluğa işaret eder. Aslında Kadro içinde komünist bir geçmişe sahip olmayan tek insan Yakup Kadri'dir. Kadro deneyimi öncesinde bir dönem Bektaşi tekkelerine devam etmiş, mistisizm, 
birey ve onun psikolojisiyle yakından ilgilenmiştir. Fecr-i Âti etkisindeyken "sanat sanat içindir" görüşünü savunmuş, toplumsal konulara Millî Mücadele yıllarından sonra ilgi göstermiştir. Kadro'ya katıldığında ise, artık "Her san'at eseri onu vücuda getiren san'atkârdan evvel cemiyetin malıdır. Çünkü, san'atkârın kendisi, bir tesadüfün veya esrarengiz bir takım kudretlerin meydana attı̆̆ bir mahlûk değil, doğrudan doğruya cemiyetin mahsulü bir insandır" diyebilecek biridir ("Ferdiyet ve Şahsiyet" 1932: 24). Hüseyin Cahit, Yakup Kadri'nin inkılâbı bir "iman" gibi benimsediğini belirtir. "Bu iman ona sanatı, edebiyatı, tetkik ve müşahadeyi, şeniyeti, hakiki hayatı, her şeyi, her şeyi unutturacak kadar hâkimdir” (alıntılayan Tekeli 2003: 383). Hüseyin Cahit, Yakup Kadri'nin bu "yeni iman"a ne kadar bağlı olduğunu görmek için Ankara'yı okumak gerektiğini söyler. $\mathrm{Bu}$ roman Yakup Kadri'nin tam da bu dönemde yazdiğı ve 1934'te yayımlanan bir eseridir. Dolayısıyla Kadrocu düşüncelerden fazlasıyla etkilenmiş, hatta Kadro’nun roman biçimindeki bir ifadesi gibidir.

\section{Bir Kadro Kitab1 Olarak Ankara}

Ankara romanı üç bölümden oluşmaktadır. Birinci bölümde Millî Mücadele yıllarının, Sakarya Savaşı öncesinin Ankara’sını buluruz. Banka muamelât şefi Ahmet Nazif Bey ve onun karısı Selma Hanım, İstanbul'dan gelmişler ve Ankara'da Tacettin mahallesinde yaşamaya başlamışlardır. Selma Hanım, önceleri içinde bulunduğu Millî Mücadele ruhunu kavrayamaz ve halkın ilkel yaşantısından şikâyet eder. Kiraladıkları ev, tahtakurusundan, "binanın bütün deliklerine sinmiş aptesane kokusundan" ve pislikten geçilmemektedir. Yazar, ev sahipleriyle ortaklaşa kullandıkları avluyu şu şekilde betimler: "Bulaşık sulariyle yağlanmış bir oluk sokak kapısının altından dışarıya uzanıyor. Onun biraz ötesinde tahtadan bir nöbetçi kulübesini andıran aptesanenin kötü kokusu dağılıyor ve ipte sıra sıra çocuk bezleri sarkıyordu. İşte, bunların altında bir adam, bir kadını döğüyordu" (1983: 24).

Selma Hanım, bir gün kocası Nazif Bey'in arkadaşları olan ve Etlik'te yaşayan Murat Bey ve Binbaşı Hakkı Bey ile tanışır. Binbaşı Hakkı Bey, Millî Mücadeleye destek veren yurtsever biridir. Selma Hanım, onun görünüşünden, cesaretinden ve en çok da şu gibi sözlerinden etkilenir: "Avrupa medeniyeti. $\mathrm{Bu}$, Avrupalının uydurduğu yüz bin yalandan biridir. Yuf bize ki kendimizi bildiğimizden beri bu yalana bir nas gibi inanmışı. Hak ve adalet prensiplerinin kaynağı hep orasıdır sanmışız. Yalan, yalan, yalan... Avrupa bir yırtıc1kuşlar yuvasıdır ve onun karşısına ancak tepeden tırnağa kadar silâhlanmış olarak çıkılır" (1983: 46). Binbaşı Hakkı Bey'in ağzından aktarılan bu düşünceler, yukarıda da ele alındığı gibi, Kadro dergisinin Anti-Avrupamerkezci görüşleriyle yakından ilişkilidir. Selma Hanım ile Hakkı Bey arasında işte bu gibi görüşler nedeniyle bir yakınlık doğar. Sık sık gezintiye çıkmaya başlarlar. 
$\mathrm{Bu}$ gezmelerden birinde "bir küçük yarın ucunda, kocaman ağaçlar arasından, kayalara yaslanmış dört köşe bir taş bina” görürler (1983: 68). Binbaşı Hakkı Bey, "İşte, Paşa'nın evi burası" der. Selma Hanım çok şaşırır; "bütün dünyanın kendisinden bahsettiği Adam, bu kayaların dibindeki taştan kulübede mi otur[maktadır]" (1983: 68). Binbaşı Hakkı Bey, "kira ile oturuyorlar" der ve Selma Hanım'ın yüreğine "ancak mübarek abideler önünde hissedilen bir huşu" çöker. Genç kadın, tekrar başını kaldırdığında her yeri değişmiş bulur; artık bütün Ankara'yı başka türlü görmektedir.

Bu sırada Sakarya Savaşı başlar. Herkes bir şekilde bu savaştan kaçmanın, Kayseri'ye gitmenin yollarını arar. Bunlardan biri de Selma Hanımın kocası Ahmet Nazif Bey'dir. Selma Hanım, kocasının millî iradeden yoksun olduğunu görerek ondan boşanır. Binbaşı Hakkı Bey'le birlikte Eskişehir'e Millî Mücadeleye katılmaya gider. Askerî hastanede kendisine bir hastabakıc1lı görevi verilmiştir. Çok geçmeden Sakarya kıyılarından ilk zafer haberleri gelir. Anlatıcı, Selma Hanım’daki değişimi şu şekilde ifade eder: "Bu devir, Selma Hanım için, yalnız karılık kocalık bakımından değil, fikirce, hisce bütün benliğine şamil bir inkılâbın kaynağı oldu. Nazif'ten ayrıldıkça Ankara'ya, Ankara'nın ifade ettiği millî mânaya bağlllı̆̆1 artıyordu" (1983: 91). Selma Hanım için artık "asker kıyafeti haricinde bir erkek timsali, tasavvuru kabil olmayan cinsiyetsiz bir şey"dir (1983: 88). Bu nedenle Hakkı Bey’i her görüşünde derin bir heyecan duyar ve gittikçe ona daha çok bağlanır.

İkinci bölümde Selma Hanım’ Binbaşı Hakkı Bey'in karısı olarak buluruz. Bu bölümde konu, Cumhuriyet'in ilanını izleyen yılların Ankara'sıdır. Binbaşı Hakkı Bey, yeni ortamın yarattığı, uzun saçlı ve bıyıkları kesilmiş bir insandır artık; askerlikten ayrılarak bir şirketin idare meclisine başkan seçilmiştir. Selma Hanım lüks ve ihtişamdan kurulu bir hayatın içinde mutsuzdur. Hakkı Bey'in değişmesi, onu çok sarsar. Her defasında ona "Nerede o tunç rengin? Nerede o çelik gövden? Nerede o sert ağzın?” (1983: 96) diye soracağı gelir. Eski millî mücadelecilerden bazıları gibi, Hakkı Bey için de kıyafet değişiminden sonra millî dâva, "bir mondenlik [şıklık] iddiası" şekline girmiştir (1983: 102). Bir Avrupalı gibi giyinip süslenmek, bir Avrupalı gibi dans etmek, bir Avrupalı gibi yaşayıp eğlenmek ve hele bu iddiada Avrupalılar nezdinde muvaffak olmak, bu insanlara büyük bir zafer kazanmak kadar önemli görünmektedir. Hakkı Bey gibi, Murat Bey de lüks içinde yaşamakta, Kavaklıdere'de modern bir köşkte oturmaktadır. "Devrimler, özlemler, halkın geleceğine ait tasarılar, arka arkaya iflâs etmektedir”. Şık kıyafetleri ve takılarıyla hayatını balolarda geçiren Selma Hanım, bu yaşam tarzından rahatsızlı̆̆ını şu şekilde dile getirir:

Demin otelin merdivenlerinden ç1karken tuhaf bir başdönmesi hissettim. Bana öyle geldi ki, ayağımı bastı̆̆ım her basamak, halkla benim aramdaki uçurumu bir parça daha derinleştiriyor. Ters yüzü geri dönüp 
Arkamda bıraktığım bu uçuruma atılmak istedim; ta ki onlara karışayım ve içinde bulunduğumuz bu sunî âlemi, onların arasından, onların gözüyle uzaktan seyredeyim diye. (1983:109)

Binbaşı Hakkı Bey, balolarda farklı kadınlarla dans etmek peşinde koşarken Selma Hanım, sıkıntılı bir şekilde bu yaşama katlanmaktadır. Bir gün Millî Mücadele yıllarında tanıştığı biriyle karşılaşır. Bu kişi, Cumhuriyet ruhunun yetiştirdiği ilk aydın gençlerden biri olan Neşet Sabit'tir. Neşet Sabit, Binbaşı Hakkı Bey gibi insanları, "cemiyet harici ve cemiyete rağmen yaşıyan müfrit ferdiyetçiler" olarak görür ve "ben, inkılâbı hiçbir zaman, hayatın dış şekillerini değiştirmek mânasına almadım. Hele bir konfor ihtiyacı, bir konfora eriş cehti mânasına hiç alamıyorum" der (1983: 118). Neşet Sabit de Selma Hanım gibi, Cumhuriyet'in yanlış bir yöne gittiğinden şikayet etmekte ve Millî Mücadele devrindeki sade ve samimi hayatı özlemektedir. Neşet Sabit'e göre, "Türk kadını, hürriyetini dans etmek, tırnaklarını boyamak ve 'Rue de la Paix'nin kanunlarına esir bir süslü kukla olmak için değil, yeni Türkiye'nin kuruluşunda ve kalkınışında kendisine düşen ciddî ve ağır vazifeyi görmek için isteyecekti, kullanacaktı" (1983: 129). Aynı şekilde, Türk erkekleri de, "garplılaşma hareketini, Tanzimat beyinin garpperestliğiyle, alafrangalığıyla bir ayarda tutmayacaktı”(1983: 129).

Anlatıcının Neşet Sabit'in ağzından aktardığı neredeyse bütün görüşler, bir Kadro düşüncesi olarak okunabilir. Yazar, "inkılâbın yanlış anlaşılmasından doğan yanlış yaşama tarzlarını”, ikinci bölüm boyunca Neşet Sabit aracılığıyla eleştirir. Örneğin şu kısım, bir "üçüncü yol” arayışı içinde olan ve Batılılaşmayı eleştiren Kadrocu görüşlerden biridir:

Milliyetçi Türk garpçısı için garpçılığın en karakteristik vasfi garplılığa Türk üslûbunu, Türk damgasını vurmaktır. Şapka bize hâkim değil biz şapkaya hâkim olmalıydık. Garplılaşma muayyen bir hayat prensibidir. Bu prensip, ancak, millî iradenin, millî isteğin, millî kültürün ve nihayet millî ahlâkın hizmetçisi, emirberi olmak şartiyledir ki, yaratıcı ve kurucu rolünü ifa edebilirdi. [....] Biz Garp namına Garpta hüküm süren çürümüş bir sınıfın istihlâk ve istihsal şartlarını kendimize tatbike uğraşmaktay1z. (1983: 130)

Yakup Kadri, Kadro'nun ilk sayısında yer alan "Şairin Bize Anlatacağı Şey Kaldı mı?” başlıklı yazısında "Bizim bulunduğumuz şu devre ikinci Orta Çăgdır" (1932: 30) nitelemesini kullaniyordu. Ankara romanında da, bir yanda balolarda yaşayan zenginler, diğer yanda elektrikle bile henüz tanışmamış yoksul halkla, benzer bir Ortaçağ tablosu oluşturulmaktadır. Neşet Sabit, Ankara'nın yeni caddelerinden geçerken "Bu ıssızlığın bu kadar aydınlığa ne ihtiyacı var?" diye sorar (1983: 128). İki üç kilometre ilerde ise karanlık sokaklarda ellerinde yağlı fenerlerle mevlüde giden insanları görür. Anlatıcı, bu sahneyi "bir ortaçağ Asya’sının göbeği” olarak niteler (1983: 132). 
Romanda Neşet Sabit'in inkılâbın yanlış anlaşıldığına ilişkin görüşleri, Selma Hanım'ın sıkıntılarına da tercüman olmaktadır. Selma Hanım, gittikçe Neşet Sabit'e daha çok yaklaşır. Hakkı Bey'le ise, artık yataklarını da ayırmışlardır. Hakkı Bey, hayatının refah seviyesi yükseldikçe bir takım "aristokratik zevkler ve itiyatlar" edinmektedir. Bu "kibar evlilik üslûbu" da bunlardan biridir (1983: 141). Bir gün Hakkı Bey’i karşısına alarak çalışmak istediğini söyler: "Hayatımı kazanmak için değil, fakat bir şeye yaramak için. Bizi, yalnız süsleyip dans ettirmek için mi açtınız? Yalnız buna yarayan bir kadın hürriyetinin ne kıymeti var?” (1983: 145). Hakkı Bey, bu sözler karşısında Selma Hanım'la yalnizca alay eder.

Selma Hanım, Hakkı Bey'in yabancı kadınlarla flört etmesini bundan birkaç yıl önce "mutaassıp Avrupalı düşmanı” bir adamın karısı olarak son derece yaralayıcı bulur. Anlatıcı bunu şu şekilde aktarır: "Bari, Hakkı Beyin bu münasebeti bir Türk hanımiyle olsaydı. Genç kadın, gurur ve haysiyetinin bu kadar kırılışına, bu kadar ayaklar altına alınıp çiğnenişine, belki, boyun eğecekti. Fakat kocasının bir ecnebi kadınla bu alâkası, ona karşı iki katlı bir ihanetti. Onu, hem cinsiyetinde, hem milliyetinde yaralıyordu" (1983: 147).

Selma Hanım, "hiç değilse bir sefalet ve azap ortaklı̆̆ı vardı" diyerek Tacettin mahallesindeki günlerini aramaktadır. "Yeni Ankara, o eski Ankara'nın bir mütekâmil şekli olmak lâzım gelmez miydi? $\mathrm{O}$ millî ateşin hararetinden bu buzdan şehir maketi nasıl çıkmıştı?” (1983: 143) diye düşünür ve bir iş bulup Tacettin mahallesinde oturmayı tasarlar. Bu nedenle oturdukları eski evi ziyarete gider. Ancak bundan hiç memnun kalmaz. Çünkü eski mahallesi ve evi hâlen o eski pislik içindedir. Cumhuriyet, bir parça olsun değiştirememiştir burayı; "büyük sahnişin sırıklarından birinde bir kocaman çiviye asılı duran paçavra parçasını bile hâlâ yerinde sallanır" bir şekilde bulur (1983: 155). Selma Hanım, buraya taşınıp yaşamaktan vazgeçer ve zihninde bir muhasebeye girişir:

Buralara gelip nasıl oturabileceğim? Eyvah bana, eyvah bana!... Bir balo gecesi, Neşet Sabit'e (Azizim, demokrasilerde yukarıdan aşağ1ya doğru inmek yoktur. Hep aşağıdan yukarıya doğru çıkmak vardır. Bunun aksi, ancak bir katastrofu ifade eder) diyen adamın meğer, ne kadar hakkı varmış. Bir katastrof? Lâkin, benim halim bir katastrof değil de nedir. (1983: 158)

Selma Hanım tarafından dile getirilen bu düşünceler de, inkılâbın “yukarıdan aşağıya" ve "halka rağmen halk için" şeklinde nitelenen ideolojisine Kadrocu bir eleştiridir. Kadro’nun bu ideolojinin dışında olduğunu göstermeyen bu yaklaşım, inkılâbın yanlış anlaşılması durumunda aydınları işte bu hâle, Selma Hanım'ın bulunduğu hâle sokmaktadır. Romanın ikinci bölümü bu şekilde bir “çıkmaz”la son bulur. Denebilir ki, Selma Hanım’ın bundan sonraki yaşamını ancak bir ütopya kurtarabilir. 
Üçüncü bölüm, Yakup Kadri’nin kitaba eklediği notta da belirtildiği gibi "romanın ütopya kısmı”dır. Bu bölümde Cumhuriyet' in 14. (1937) ve 20. (1943) yıllarının Ankara'sı konu edilmiştir. Bölümün başında bir kutlama betimlemesi yer alır ve bundan Cumhuriyet' in başarılı olduğu, amaçlarına ulaştığı anlaşılmaktadır. Törende yer alan Mustafa Kemal'in profili bir "Tanrı kafası" gibi betimlenmektedir: "Bu alın, çok geniş olmamakla beraber, eski Yunan heykeltraşlarına bir genç Tanrı kafası örneği olacak derecede düzgün, âhenkli ve yontulmuş idi” (1983: 162). Bu düşünce, aynı zamanda Yakup Kadri'nin Ankara romaniyla ya da Kadro hareketi dönemiyle sinırlı olmayan Mustafa Kemal hayranlığının da bir ifadesidir. Yakup Kadri, Atatürk adlı kitabında "yiğitlerin en yiğidi, dâhilerin en dâhisi, inkılâpçıların en inkılâpçısı ve devlet adamlarının en mükemmeli” (2000: 35) olarak gördüğü Mustafa Kemal'i, Nietzsche'nin ünlü kavramından yararlanarak "insandan üstün insan” kategorisinde değerlendirmektedir (2000: 38).

Romanda Cumhuriyet'in başarısı ise "dünyanın ikinci yaratılışı" gibi görülmektedir: "Bu bir (dünyanın ikinci yaradılışı) idi. Bundan dört yıl evvel yüzünü gördüğü ve sesini işittiği Tanrı, aydınlığa, ol! demişti; aydınlık oluyordu. Suya ol! demişti, su oluyordu ve 'suların arasında Levh olsun' demişti. Levh, meydana gelmişti” (1983: 163). Bu mistik sayllabilecek betimlemeler, Kadrocu görüş̧te inkılâbı bir din gibi kavramanın egemen olduğunu anımsatmaktadır. Örneğin, Şevket Süreyya, dergideki "İnkılâp Heyecanı (Antuziasm)" başlıklı bir yazısında "inkılâp heyecanını, hattâ sade bir ahlâk değil, yeni bir din gibi mukaddesleştirelim” der (1932: 8). Yakup Kadri ise, Ankara'da buna uygun dinsel betimlemelere başvurmaktadır. Romanın başka bir yerinde geleceğin bir cennet gibi betimlendiğini görürüz: "Elebaşı ortaya çıkıp da 'Haydi, çocuklar...' diye söze başlarken bütün içtiği limonatalar, midesinin içinde en yüksek markadan şampanyalar haline girip beynine vurur ve herkesten evvel ayaklanırdı" (1983: 188). Burada, yalnızca cennette bulunan "haram olmayan içkilerin de sarhoşluk yapıcı etkisinin olacağı” söz konusudur.

Üçüncü bölümde Selma Hanım, Hakkı Bey'den ayrılmış ve üçüncü evliliğini Neşet Sabit ile yapmıştır. Kendilerini kültür ve sanata vermişler ve mutlu bir beraberliğe başlamışlardır. Boş vakitlerini ise halkla birlikte eğlenerek değerlendirmekte, "halk içinde ve halkla beraber eğlenmekte daha büyük bir zevk" olduğunu düşünmektedirler (1983: 165). Selma Hanım için Ankara, artık onun kendi evi gibidir. Anlatıcı, Ankara'nın bu güzelliğe "millî kurtuluş prensiplerine dayanan bir iktisadî kalkınma savaşı” yla kavuştuğunu belirtir (1983: 168). Her şey değişmiştir. Matbuat, "ötekinin berikinin şeref ve haysiyetine tecavüz" eden yayınlar yapmaktan vazgeçmiş, "millî gayelere ve millî göreneklere aykırı hareket edenlerin amme efkârı huzurundaki cezalarını ancak zekânın en keskin tedip [terbiye] silahı olan istihza" ile vermektedir. Bu sa- 
yede artık "nice kötü âdetler, gayri millî cereyanlar, tereddi ve irtica unsurları" toplumda barınamamaktadır. Anlatıcı sanattaki değişmeyi ise şu şekilde dile getirir:

Sinemalar, [...] artık, halkın aşağı duygularına hitap eden ve hep insanlığın hayvanlık kısmını gicıklayan, âdi, bayağı ve zevksiz filmler çevirmekten vazgeçmişler, bunun yerine millî davalara hizmet eden satirik ve epik filmler yapmağa başlamışlard. Halk, bunları da aynı alâka ve tehalükle seyrediyor; bunlara bakarken de, Greta Garbo'nun âşıklarına ağladığı, Charlie Chaplin’in düşüp kalkışlarına güldüğü kadar ağlayıp gülmesini biliyordu. (1983: 170)

Ankara, Selma Hanım ile Neşet Sabit kadar, halkın da "sınırsız bir mutluluğa" kavuşmasıyla son bulur. Romanın son sahnesi, Cumhuriyet' in 20. yıldönümü nedeniyle düzenlenen şenliklere ayrılmıştır. Halkın Mustafa Kemal ve İsmet Paşa ile buluştuğu bu şenliklerde "her fert ruhça olduğu gibi bedence de bütün şahsî duygulardan sıyrılmış ve on bin kişi bir adam, bir adam on bin kişi olmuştu[r]” (1983: 213).

Romanın buraya kadar alıntılanan ve aktarılan kısımlarında da görüldüğü gibi, bazı bölümler belirgin şekilde Kadrocu görüşün etkisi altındadır. Yukarıda da ifade edildiği üzere "Anti-Avrupamerkezcilik", "inkılâbın yanlış anlaşılması", "üçüncü yol", "Batıllıaşma", "devrimin yukarıdan aşağıya niteliği", "inkılâbın bir din gibi benimsenmesi” gibi konularda roman, Kadrocu bir yazar tarafindan yazıldığını açık bir şekilde belli eder. Anlatıının, Ankara'nın güzelliğe "millî kurtuluş prensiplerine dayanan bir iktisadî kalkınma savaşı"yla kavuştuğunu belirtmesi ise, Kadro'nun savunduğu ve gelecek için kaçınılmaz bir şekilde öngördüğü temel düşüncelerden birinin ifadesidir. Romandaki bazı bölümler, Yakup Kadri'nin yaşamından da izler taşır. Örneğin, Selma Hanım'ın ve Nazif Bey'in İstanbul'dan Ankara’ya gelişlerinin anlatıldığı ilk bölüm, Yakup Kadri'nin 1921'de Ankara'ya ilk kez geldiği günlerdeki yolculuklarından sağladığı malzemelerden kurulmuştur (Tekeli, İlkin 2003: 36). Ayrıca, romanın ikinci bölümünde ele aldığı, inkılâbı salon yaşamına indirgeyen "firsatçı ve görgüsüz çevre"den Ergenekon adlı kitabında da söz etmiştir.

İlhan Tekeli ve Selim İlkin'in Kadrocuları ve Kadro'yu Anlamak adlı kitabında da belirtildiği gibi, Ankara romanını iyi yorumlayabilmek için Kadro hareketinin iyi anlaşılması gerekmektedir. "Selma Hanım'ın yaşadığı Cumhuriyet'in ilk on yıll, Kadro gözüyle Cumhuriyet'in bir eleştirisidir”. Romanın üçüncü bölümünde Cumhuriyet'in ikinci on yılı için yapılan kurmaca ise, aslında Kadrocuların "Cumhuriyet ütopyalarının romanlaştırılmasıdır" (2003: 382). İlginç olan, romanın her bölümünde Selma Hanım'ın başka bir erkekle evlenmesidir. Selma Hanım, Cumhuriyet öncesi millî mücadele yıllarında $\mathrm{Na}-$ zif Bey'in, Cumhuriyet'in ilk yıllarında Hakkı Bey'in, Cumhuriyet'in ikinci 
on yılında ise Neşet Sabit'in karısıdır. Selma Hanımın kendisi ya da toplumsal düzen değiştikçe, kocaları da değişir. Bunu Nurdan Gürbilek, şu şekilde yorumlar: "[U]mumun hayatına biçim veren her şey Selma Hanım'ın özel yaşamında doğrudan karşılı̆̆ıını bulur. [....] Kamuyla özel hayat arasındaki ilişki son derece kabadır: Oradaki her değişiklik özel hayata doğrudan yansıyacak, şehrin her dönemi yeni bir kocayı gerektirecektir” (1992: 62). Bu şekilde bir yorum, bu konuda da bizi Kadro’ya, daha doğru bir deyişle Kemalizm’e götürür. Kemalizm'de de, örneğin "laiklik" sorununda kamu ile özel hayat birbirine girmiş, sınırlarını yitirmiştir.

Fethi Naci'nin "şematik" olduğu gerekçesiyle "alabildiğine zayıf bir roman” şeklinde nitelediği (2009: 72) Ankara’ya bir roman olarak baktığımızda ise, tipik bir kurgu ve olay örgüsü ile karşılaşırız. Tezi olan bir roman olduğu için sürprizler, düğümler, çözümler bulunmaz. Kitabın bazı bölümlerinde Yakup Kadri’nin edebî bir kaygı taşıdığı da söylenebilir. Örneğin, sayfalarca Selma Hanım'ın yaşlılık kompleksinden ve kıskançlık krizlerinden söz edilmektedir:

Bir sabah, gazetelerin birinde, gözüne şöyle bir ilân ilişti: 'Gençlik eksiri! - Ankara Büyük Merkez Lâboratuvarı istihzaratından olan bu suyu ciltlerinin tazeliğini muhafaza etmek isteyenlere salık veririz. Bütün kırışıklıkları giderir. vs.' Selma Hanım, hemen, bu ilaçtan getirtti, içindeki tarifeye göre kullanmağa başladı. (1983: 193)

Yazar bu bölümlere, büyük olasılıkla romana farklı bir atmosfer kazandırmak ve durgunluğu kırmak gibi nedenlerle yer vermiştir. Ancak bu, baştan sona bir tezin işlendiği bir romanda eklektik ve ayrıksı durmakta, romanın kurgusuna olumlu katkıda bulunacağı yerde, onu daha da dağınık bir hâle getirmektedir.

Sonuç olarak, Ankara'yı roman sanatına yeni bir anlatım biçimi kazandıran bir kitap olarak değil, Türkiye'nin siyasal düşünce tarihinde iz bırakmış süreçlerinden biri olan Kadro hareketini daha iyi anlamak için bir "araç" olarak görmenin yerinde olacağ1 söylenebilir. Yakup Kadri, bu kitabında roman sanatını inkılâba olan inancına feda etmiş olsa da, Kadro’ya özgü tezini başarılı bir şekilde işlemiştir. 


\section{Kaynaklar}

Aydemir, Şevket Süreyya (Şubat 1932). "İnkılâp Heyecanı (Antuziasm)”, Kadro 2, s.5-8.

(Mart 1932). “İnk1lâp Bitti mi?”, Kadro 3, s.5-10.

_ (Temmuz 1932). “'Europacentrisme’in Tasfiyesi”, Kadro 7, s.5-8. (1968). Inkılâp ve Kadro, İstanbul: Bilgi Yayınevi.

Belge, Burhan Asaf (Ocak 1932). "İnkılâbımız ve Hilâfet”, Kadro 1, s.38-41.

Fethi Naci (2009). “Ankara”, Yüz Yılın 100 Türk Romanı, İstanbul: Türkiye İş Bankası Kültür Yayınları, s.71-77.

Gürbilek, Nurdan (1992). Vitrinde Yaşamak: 1980’lerin Kültürel İklimi, İstanbul: Metis Yayınları.

“Kadro [1]" (Ocak 1932). Kadro 1, s.3. İmzasız başyazı.

"Kadro [2]" (Şubat 1932). Kadro 2, s.3-4. İmzasız başyazı.

"Kadro [6]" (Haziran 1932). Kadro 6, s.3-4. İmzasız başyazı.

Karaosmanoğlu, Yakup Kadri (Ocak 1932). “Şairin, Bize Anlatacağ Kadro 1, s.28-30.

- (Temmuz 1932). "Ferdiyet ve Şahsiyet", Kadro 7, s.24-25.

— (1983). Ankara, İstanbul: İletişim Yayınları.

— (2000). Atatürk: Biyografik Tablil Denemesi, İstanbul: İletişim Yayınları.

—— (2000). "Büyük İnkılâp ve Küçük Politika", Atatürk: Biyografik Tahlil Denemesi, İstanbul: İletişim Yayınları, s.145-85.

— (2006). Zoraki Diplomat, İstanbul: İletişim Yayınları.

- (2010). Ergenekon: Millî Mücadele Yazıları, İstanbul: İletişim Yayınları.

Talay, Birsen (2002). "Yakup Kadri Karaosmanoğlu”, Modern Türkiye'de Siyasi Düşünce: Cilt 2: Kemalizm, İstanbul: İletişim Yayınları, s.430-41.

Tekeli, İlhan ve Selim İlkin (2003). Bir Cumburiyet Öyküsü: Kadrocuları ve Kadro'yu Anlamak, İstanbul: Tarih Vakfi Yurt Yayınları.

Tör, Vedat Nedim (Ocak 1932). "Müstemleke İktisadiyatından Millet İktisadiyatına”, Kadro 1, s.8-11.

__ (Şubat 1932). "Müstemleke İktisadiyatından Millet İktisadiyatına 2", Kadro 2, s.9-14.

—_ (Haziran 1932). "Niçin ve Nasıl Sanayileşmemiz Lâzım?”, Kadro 6, s.13-18.

Türkeş, Mustafa (2002). "Kadro Dergisi”, Modern Türkiye’de Siyasi Düşünce: Cilt 2: Kemalizm, İstanbul: İletişim Yayınları, s.464-76.

Türkeş, Ömer (2002). "Güdük Bir Edebiyat Kanonu”, Modern Türkiye'de Siyasi Düşünce: Cilt 2: Kemalizm, İstanbul: İletişim Yayınları, s.425-48. 


\begin{abstract}
The Kadro Movement and Ankara as a Kadro Novel

The journal Kadro, which had been published through January 1932 December 1934 for three years could only manage to be the speaker of the government. When this process disrupted and began to damage the power of the government, its existence had started to be questioned, and in a sense it had been prevented from being a "pioneer cadre". Thereby both its searching of being a third way between socialism and capitalism, and its "ambitions" of being a pioneer could have only been an utopia. Yakup Kadri Karaosmanoğlu was one of the important writers of the journal, and his novel entitled Ankara could be read as a fictional expression of Kadro movement which took the road with a big "enthusiasm of revolution" and then exterminated silently. In this article, primarily the relationship between the Kadro movement and the government, and then its ideological tendencies will be discussed. Finally, certain ideas and discussions portrayed in Ankara will be read considering the Kadro movement.
\end{abstract}

Keywords: Republic, goverment, Kadro, Yakup Kadri Karaosmanoğlu, Ankara 
